\title{
Epidemiological study of prevalence of chlorpropamide alcohol flushing in insulin dependent diabetics, non-insulin dependent diabetics, and non-diabetics
}

\author{
S NG TANG FUI， H KEEN, R J JARRETT, C STRAKOSCH，T MURRELLS, P MARSDEN, \\ R STOTT
}

\begin{abstract}
An epidemiological study was carried out to compare the prevalence of facial flushing in non-diabetics, patients with insulin dependent diabetes, and patients with non-insulin dependent diabetes in response to $40 \mathrm{ml}$ sherry taken 12 hours after $250 \mathrm{mg}$ chlorpropamide or placebo, administered double blind in randomised order. A flush after chlorpropamide but not placebo was reported by $6.2 \%$ of non-diabetics $(17 / 273), 9.7 \%$ of insulin-dependent diabetics (14/145), and $10.5 \%$ of noninsulin dependent diabetics (25/239), excluding those receiving long term chlorpropamide treatment. The differences were not significant. This response was unrelated to age, sex, body mass index, and family history of diabetes in all three groups. Patients taking long term chlorpropamide, however, showed a significantly $(p<0.01)$ higher prevalence of flushing after both chlorpropamide and placebo $(56 \cdot 3 \% ; 9 / 16)$ compared with the rest of the non-insulin dependent diabetics $(16.7 \% ; 40 / 239)$, the insulin dependent diabetics $(6.9 \%$; 10/145), and the non-diabetics $(5.9 \% ; 16 / 273)$. Patients receiving long term chlorpropamide would be expected to flush with sherry after a placebo tablet because of therapeutic plasma concentrations of the drug.

It is concluded that there is no evidence of an increased prevalence of chlorpropamide alcohol flushing in response to the single challenge test in non-insulin dependent diabetics compared with insulin dependent diabetics and non-diabetics except in selected patients taking chlorpropamide long term. This study does not support the hypothesis that the chlorpropamide alcohol flush is a specific marker for a subtype of non-insulin dependent diabetes.
\end{abstract}

\section{Introduction}

In the late 1950s several reports drew attention to the intense facial flush experienced by patients treated with chlorpropamide when they drank even small amounts of alcohol. ${ }^{1-5}$ The term chlorpropamide alcohol flush was later coined by Leslie and Pyke $^{6}$ to denote this particular response, which is distinct

\footnotetext{
Unit for Metabolic Medicine, Guy's Hospital and Medical School, London SE1 9RT

S NG TANG FUI, MSC, MRCP, Medical Research Council research fellow and honorary senior registrar

H KEEN, MD, FRCP, professor

R J JARRETT, $M D$, reader in community medicine

C STRAKOSCH, MD, FRACP, research fellow

T MURRELLS, BSC, MSC, research statistician

Diabetic Clinic, Greenwich District Hospital, London SE10 P MARSDEN, MD, FRCP, consultant physician

Diabetic Clinic, Lewisham Hospital, London SE13

R STOTT, FRCP, consultant physician

Correspondence to: Professor H Keen.
}

from the flush resulting from sensitivity to alcohol alone, seen commonly in Chinese and other Mongoloid peoples. ${ }^{78}$ Chlorpropamide alcohol flushing was reported in $10-35 \%$ of patients treated with chlorpropamide, ${ }^{1-5}$ but, as pointed out by Fitzgerald et al, ${ }^{9}$ many diabetics abstain from alcohol and others may not report the reaction. They found that of 100 patients taking chlorpropamide, 33 did not drink alcohol and 22 of the remainder had experienced facial flushing after alcohol.

After observing chlorpropamide alcohol flushing in a diabetic woman and her two diabetic daughters Leslie and Pyke investigated a possible genetic link between the response and diabetes, by using a standard "single challenge" test. ${ }^{6}$ A single preparatory $250 \mathrm{mg}$ dose of chlorpropamide or a placebo tablet was followed 12 hours later by $40 \mathrm{ml}$ sherry. The response was considered to be positive if the subject complained of, or admitted to, a sensation of facial flush only after the chlorpropamide preparation. Positive responses occurred in $51 \%$ of 234 patients with non-insulin dependent diabetes mellitus ( $81 \%$ of those with a family history of diabetes) compared with only $10 \%$ of 60 patients with insulin dependent diabetes mellitus and $10 \%$ of 60 non-diabetic controls. ${ }^{6}$ These findings and the results of studies of families and twins ${ }^{6}{ }^{10}$ led them to propose that the chlorpropamide alcohol flush may represent a genetic marker for a common subtype of non-insulin dependent diabetes with strong familial occurrence.

We report an epidemiologically based study in which we compared the prevalence of chlorpropamide alcohol flushing in populations of patients with non-insulin dependent diabetes, patients with insulin dependent diabetes, and non-diabetic volunteers.

\section{Subjects and methods}

We randomly selected 800 patients with insulin dependent or noninsulin dependent diabetes and 800 non-diabetic subjects and asked them to participate in the study.

Diabetics-Over one year the clinical notes of all patients aged 20-79 routinely attending the diabetic clinics of Greenwich and Lewisham district general hospitals were systematically examined. Every week two patients were randomly selected from each decade of age and either sex to a total of 800 . The details of the study were fully explained to each participant and written consent requested. The study was approved by the ethical committees of the hospitals concerned. The patients were classified as insulin dependent or noninsulin dependent ${ }^{11}$ according to the following rules. (1) All diabetics not receiving insulin injections were classed as having non-insulin dependent diabetes. (2) For those patients injecting insulin a history of unbroken insulin treatment from the time of diagnosis (excepting short breaks of up to a month) was accepted as indicating insulin dependent diabetes. (3) All other patients receiving insulin were classed as having non-insulin dependent diabetes unless insulin had been started during an episode of severe ketosis and continued subsequently, in which case they were classed as having insulin dependent diabetes. These three rules could not be applied in four cases, and these patients were excluded.

Non-diabetics-Control subjects were recruited from the staff of the Greater London Council after approval for the study by their medical and staff associations and explanation in their house journal. Eight hundred employees were randomly selected to provide 100 subjects of each sex in each decade of age group between 20 and 59 years. Known diabetics were excluded. Due to selective retirement 
TABLE I-Proportions of each diagnostic group who consented to participate in study and reasons for refusal

\begin{tabular}{llcc}
\hline & Non-diabetics & $\begin{array}{c}\text { Insulin } \\
\text { dependent } \\
\text { diabetics }\end{array}$ & $\begin{array}{c}\text { Non-insulin } \\
\text { dependent } \\
\text { diabetics }\end{array}$ \\
\hline No invited & 800 & 275 & 521 \\
No (\%) who consented & $411(51 \cdot 4)$ & $221(80 \cdot 4)$ & $401(77 \cdot 0)$ \\
No (\%) who did not reply & $177(22 \cdot 1)$ & NA & NA \\
No \% \% wh refused & $212(26 \cdot 5)$ & $54(19 \cdot 6)$ & $120(23 \cdot 0)$ \\
Disliked being "experimented & 27 & 9 & 11 \\
on" or too busy & 27 & 19 & 38 \\
Pregnancy or other medical & 39 & 3 & 4 \\
$\quad$ reason & 21 & 14 & 16 \\
Thanging address & 11 & 9 & 51 \\
Nototal reason given & 114 & & \\
\hline
\end{tabular}

$\mathrm{NA}=$ Not applicable as consent was requested from the patients with diabetes by direct personal approach whereas the non-diabetic controls were asked to give consent by letter.

TABLE II-Composition by age and sex of subjects completing the tests

\begin{tabular}{|c|c|c|c|c|c|c|}
\hline \multirow{2}{*}{ Age (years) } & \multicolumn{2}{|c|}{ Non-diabetics } & \multicolumn{2}{|c|}{$\begin{array}{c}\text { Insulin } \\
\text { dependent diabetics }\end{array}$} & \multicolumn{2}{|c|}{$\begin{array}{c}\text { Non-insulin } \\
\text { dependent diabetics }\end{array}$} \\
\hline & Men & Women & Men & Women & Men & Women \\
\hline $\begin{array}{l}20-39 \\
40-59 \\
60-79\end{array}$ & $\begin{array}{l}68 \\
82\end{array}$ & $\begin{array}{l}52 \\
71\end{array}$ & $\begin{array}{l}31 \\
36 \\
19\end{array}$ & $\begin{array}{l}23 \\
21 \\
15\end{array}$ & $\begin{array}{r}4 \\
55 \\
68\end{array}$ & $\begin{array}{r}2 \\
53 \\
73\end{array}$ \\
\hline Total & 150 & 123 & 86 & 59 & 127 & 128 \\
\hline
\end{tabular}

drinks. Suggestion of an expected response was deliberately avoided, and inquiry was not limited to the presence or absence of facial response, thus differing from the technique of Leslie and Pyke. ${ }^{6}$ Each questionnaire was returned by post soon after completion. A further questionnaire also requested details of medical and family history with particular reference to diabetes, a list of all drugs taken, body weight, height, and other specified information. Tests of reproducibility and of change in facial temperature and measurements of plasma chlorpropamide and alcohol concentrations were also carried out on samples of the diabetic and non-diabetic populations ( $S N T$ Fui et al, paper to be published).

Data analysis and statistical methods-The paired questionnaires and the medical inquiry for each subject were analysed separately for the three diagnostic groups. Yates's $\chi^{2}$ test for $2 \times 2$ tables was used to compare differences in pairs. Differences between group means were tested by the unpaired Student's $t$ test.

\section{Results}

\section{COMPLIANCE}

Over three quarters of the diabetics but only about a half of the non-diabetics consented to participate in the study (table I). The reasons for non-compliance are also outlined in table I. Of those who consented to participate, $273(66.4 \%)$ of the non-diabetics, 145 $(65.6 \%)$ of the patients with insulin dependent diabetes, and 255 $(63.6 \%)$ of the patients with non-insulin dependent diabetes completed the study satisfactorily. Table II shows their composition by

TABLE III-Prevalence of responses to standard chlorpropamide alcohol flush test in each diagnostic group. Figures are numbers $(\%)$ of subjects

\begin{tabular}{|c|c|c|c|c|}
\hline \multirow[b]{2}{*}{ Diagnostic group } & \multicolumn{4}{|c|}{ Flush reported after: } \\
\hline & $\begin{array}{l}\text { Chlorpropamide } \\
\text { but not placebo }\end{array}$ & $\begin{array}{l}\text { Chlorpropamide } \\
\text { and placebo }\end{array}$ & $\begin{array}{l}\text { Placebo but not } \\
\text { chlorpropamide }\end{array}$ & $\begin{array}{l}\text { Neither chlorpropamide } \\
\text { nor placebo }\end{array}$ \\
\hline $\begin{array}{l}\text { Non-diabetics }(n=273) \\
\text { Insulin dependent diabetics }(n=145) \\
\text { Non-insulin dependent diabetics: }\end{array}$ & $\begin{array}{l}17(6 \cdot 2) \\
14(9 \cdot 7)\end{array}$ & $\begin{array}{l}16 \quad(5 \cdot 9) \\
10 \quad(6 \cdot 9)\end{array}$ & $\begin{array}{r}17(6 \cdot 2) \\
7(4 \cdot 8)\end{array}$ & $\begin{array}{l}223(81 \cdot 7) \\
114(78 \cdot 6)\end{array}$ \\
\hline $\begin{array}{l}\text { Not taking chlorpropamide }(n=239) \\
\text { Taking chlorpropamide }(n=16)\end{array}$ & $\begin{aligned} & 25(10 \cdot 5) \\
& 1(6 \cdot 3)\end{aligned}$ & $\begin{array}{r}40(16 \cdot 7) \\
9(56 \cdot 3)\end{array}$ & $13(5 \cdot 4)$ & $\begin{array}{r}161(67 \cdot 4) \\
6(37 \cdot 5)\end{array}$ \\
\hline
\end{tabular}

TABLE IV-Mean (SD) a a'e, body mass index*, and sex distribution of subjects who reported flushing after chlorpropamide but not placebo in each diagnostic group compared with values in rest of group

\begin{tabular}{lcc}
\hline & $\begin{array}{c}\text { Flush after } \\
\text { chlorpropamide only }\end{array}$ & Rest of group \\
\hline Age (years): & $41 \cdot 9(10 \cdot 9)$ & $41 \cdot 2(11 \cdot 3)$ \\
$\quad$ Non-diabetics & $47 \cdot 1(16 \cdot 0)$ & $45 \cdot 6(16 \cdot 0)$ \\
Insulin dependent diabetics & $63 \cdot 7(7 \cdot 9)$ & $59 \cdot 8(10 \cdot 8)$ \\
$\quad$ Non-insulin dependent diabetics & $23 \cdot 6(5 \cdot 2)$ & $24 \cdot 8(3 \cdot 2)$ \\
Body mass index: & $26 \cdot 6(4 \cdot 2)$ & $25 \cdot 3(3 \cdot 4)$ \\
$\quad$ Non-diabetics & $27 \cdot 1(4 \cdot 7)$ & $27 \cdot 4(5 \cdot 0)$ \\
Insulin dependent diabetics & $0 \cdot 7$ & $1 \cdot 3$ \\
$\quad$ Non-insulin dependent diabetics & $1 \cdot 0$ & $1 \cdot 5$ \\
Sex ratio (M:F): & $1 \cdot 0$ & $1 \cdot 0$ \\
$\quad$ Non-diabetics & & \\
Insulin dependent diabetics & & \\
Non-insulin dependent diabetics & & \\
\hline
\end{tabular}

*Weight $(\mathrm{kg}) /(\text { height }(\mathrm{m}))^{2}$

subjects aged over 60 were not included in the study. Each selected employee was requested by letter to give voluntary consent to take part; a single reminder was sent if no answer was received.

Test procedure-The chlorpropamide alcohol flush response was assessed using the single challenge test with placebo control as described by Leslie and Pyke ${ }^{6}$ but administered double blind and in randomised order. Each subject was instructed to take with breakfast a $250 \mathrm{mg}$ chlorpropamide or placebo tablet one week apart followed by $40 \mathrm{ml}$ sherry 12 hours later. Regular drugs were continued, but casual analgesics were forbidden for 48 hours before each test. Patients taking regular aspirin, indomethacin, or other non-steroidal anti-inflammatory drugs were excluded from the study since these drugs may block the flush response. ${ }^{12}{ }^{13}$ All participants were asked to complete a standard test questionnaire inquiring whether they had experienced any of several diverse specified symptoms, one of which was flushing of the face, during the hour after each of the two sherry age and sex. Only one test (either with chlorpropamide or placebo) was carried out by $7 \cdot 8 \%, 10.8 \%$, and $10.0 \%$ of the groups respectively, the remainder not completing either test despite having given consent. Hypoglycaemic treatment in patients with non-insulin dependent diabetes who completed the tests consisted of diet alone or with metformin (84 patients), glibenclamide alone or with metformin (96), insulin (47), chlorpropamide (16), and other drugs (12). The results for patients taking chlorpropamide therapeutically are presented separately from those for the rest of the group with noninsulin dependent diabetes because when the data were analysed these patients were found to have responded differently.

\section{TEST RESULTS}

Responses were classified into four types (table III) according to whether a flush was reported when sherry was taken after chlorpropamide but not placebo, after both chlorpropamide and placebo, after placebo but not chlorpropamide, or not at all. According to the definition of Leslie and Pyke, only the first constitutes a true chlorpropamide alcohol flush. By these criteria the prevalence of a true chlorpropamide alcohol flush in our study (table III) was $6.2 \%$ among non-diabetics, $9 \cdot 7 \%$ among patients with insulin dependent diabetes, and $10.2 \%$ among all patients with non-insulin dependent diabetes $(10.5 \%$ among those not receiving chlorpropamide therapeutically). The differences between these groups were not significant $(p>0.05)$. There was no significant difference in the prevalence of chlorpropamide alcohol flushing between subjects with and without a family history of diabetes in the group with non-insulin dependent diabetes $(7.8 \%$ and $11.9 \%$ respectively; $p>0.05)$ or in either of the two other groups. The mean age, mean body mass index (weight/ height $t^{2}$ ), and sex ratio among subjects in each diagnostic group who showed a true chlorpropamide alcohol flush did not differ significantly from those among the rest of the group (table IV). 
A flush after both chlorpropamide and placebo occurred in 56.3\% of patients with non-insulin dependent diabetes taking chlorpropamide long term compared with $16.7 \%$ of the rest of the group with non-insulin dependent diabetes, $6.9 \%$ of the group with insulin dependent diabetes, and $5.9 \%$ of the non-diabetic subjects (table III) The difference in prevalence between the patients taking chlorpropamide long term and each of the other groups was highly significant $(p<0.01)$; the prevalence among non-insulin dependent diabetics not taking chlorpropamide was also significantly different from that among the non-diabetics and among the insulin dependent diabetics $(p<0 \cdot 05)$. Further analyses of the group with non-insulin dependent diabetes did not bring to light any association between flushing after both chlorpropamide and placebo and any other chronic antidiabetic treatment besides chlorpropamide. This response occurred in nine $(10.8 \%)$ of the 84 patients taking diet alone or with metformin; $16(16.7 \%)$ of the 96 taking glibenclamide alone or with metformin; nine $(19.1 \%)$ of the 47 taking insulin; and one $(10.0 \%)$ of the 12 taking other antidiabetic drugs. There was a slight but significant $(p<0.05)$ excess of women with non-insulin dependent diabetes compared with men who flushed after both chlorpropamide and placebo $(29 / 122$ women $(23.8 \%)$ v $13 / 120$ men $(11 \cdot 1 \%))$; this difference was found in the age groups 40-59 and 60-79.

\section{Discussion}

Our study, using the single challenge test, shows no evidence of a significantly higher prevalence of flushing after chlorpropamide but not placebo in patients with non-insulin dependent diabetes compared with patients with insulin dependent diabetes and non-diabetic subjects. The response was unrelated to age, sex, body mass index, or family history of diabetes in any of the three groups. The prevalence of chlorpropamide alcohol flushing $(10.5 \%)$ in patients with non-insulin dependent diabetes, excluding those taking chlorpropamide long term, was much lower than the $51 \%$ reported by Leslie and Pyke. ${ }^{6}$ The patients taking chlorpropamide long term, however, differed from the rest of the group with non-insulin dependent diabetes and the patients with insulin dependent diabetes and the non-diabetics by having a significantly higher prevalence of flushing after both chlorpropamide and placebo (56.3\%). Because of the long term treatment with chlorpropamide they would have had therapeutic plasma concentrations of the drug whether they took a preparatory chlorpropamide or placebo tablet for the test and would therefore, if susceptible to chlorpropamide alcohol flushing, flush with alcohol after both preparations instead of only after chlorpropamide. Chronic chlorpropamide treatment thus invalidates the placebo control and increases the prevalence of chlorpropamide alcohol flushing.

Most of Leslie and Pyke's patients with non-insulin diabetes were receiving chlorpropamide therapeutically, ${ }^{6}{ }^{14}$ unlike the small proportion in our study. This may explain their apparently higher prevalence of flushing in response to the single challenge test, though no reference was made of their responses after placebo. The effect of chlorpropamide taken long term on the response would also account for the high prevalence of flush after alcohol reported by Signorelli ${ }^{1}$ and Fitzgerald et al ${ }^{9}$ in patients receiving the drug therapeutically. By contrast, Kobberling et al $^{15}$ and De Silva et al ${ }^{16}$ found that only $16 \%$ and $4 \%$ respectively of their patients with non-insulin dependent diabetes responded positively to the single dose test, and these prevalences resemble ours. None of the patients of De Silva et al was receiving chlorpropamide therapeutically, but Kobberling et al gave no details of treatment. Variations in the reported prevalence of chlorpropamide alcohol flushing in non-insulin dependent diabetes can therefore probably be attributed to the use of the single challenge test, particularly if without placebo control, in groups containing variable, often unspecified, proportions of patients receiving long term treatment with chlorpropamide.

Plasma chlorpropamide concentration rises steadily with repeated daily doses of the drug (half life of 35 hours), reaching a plateau after about a week. ${ }^{17}$ Higher prevalences of chlorpropamide alcohol flushing after chronic treatment reflect the importance of plasma chlorpropamide concentration in determining the flush response, as demonstrated by Jerntorp et $a l,{ }^{18}$ who found significantly higher concentrations in patients who showed chlorpropamide alcohol flushing than in non-responders (68.4 (SEM 9.3) and $25 \cdot 2(2 \cdot 1) \mathrm{mg} / 1$ respectively), and by our own studies $^{19}$ showing conversion of negative responses to positive by prolonged administration of chlorpropamide. Seven out of 10 patients with insulin dependent and eight out of 10 with non-insulin dependent diabetes who did not respond to the single dose test did so after receiving chlorpropamide for seven days, which resulted in a threefold increase in plasma concentration. Similar findings were reported by Pontiroli et $a l,{ }^{20}$ who showed that positive responses were eight to 10 times higher in diabetics who received four doses of $250 \mathrm{mg}$ chlorpropamide than in those who received only a single dose.

Probably, too, the intensity of the flush is related to plasma chlorpropamide concentration. Responses after a single dose of the drug may be equivocal or mild, unreproducible, or correlate imperfectly with the rise in facial temperature. ${ }^{16} 2122$ Presumably subjects who flush after a single dose represent individuals particularly susceptible to the flush-producing potential of the drug. The flush response depends on enzymes of alcohol and acetaldehyde metabolism ${ }^{23}{ }^{24}$; so it would not be surprising if it, like enzyme activity, were inherited, whether related to noninsulin dependent diabetes or not.

We conclude that there is no evidence of a specific association between the chlorpropamide alcohol flush, as determined by the single challenge test, and non-insulin dependent diabetes, high prevalences having been reported as an effect of prolonged chlorpropamide treatment in non-insulin dependent diabetics. These observations must strongly undermine the assertion that the chlorpropamide alcohol flush is a marker for non-insulin dependent diabetes with a familial occurrence.

We thank Dr T Hall and Mr J Percival of the Greater London Council for help with the recruitment of non-diabetic control subjects; the staff of the medical records departments and the diabetic clinics, Lewisham and Greenwich hospitals, for the recruitment of diabetic patients; Dr C Bulpitt of the London School of Hygiene and Tropical Medicine for epidemiological advice; International Distillers and Vintners Ltd for supplying the sherry; the staff of the unit for metabolic medicine, Guy's Hospital; and Mrs Jean Gray for secretarial help. SNTF was supported by a Medical Research Council research grant, and CS by the Guy's Hospital endowment fund trustees.

\section{References}

${ }^{1}$ Signorelli S. Tolerance for alcohol in patients on chlorpropamide. Ann NY Acad Sci 1959;74:900-3.

${ }^{2}$ Canessa I, Valiente S, Mella I. Clinical evaluation of chlorpropamide in diabetes mellitus. Ann NY Acad Sci 1959;74:752-70.

${ }^{3}$ Cardonnet LJ, Staffieri JJ, Eberhardt DR, Tommasino PO, Berli RR, Muratoria J. Clinical study of the effects of chlorpropamide on normal subjects and on diabetics. Ann NY Acad Sci 1959;74:771-87.

${ }^{4}$ Salcedo I, Borges F. The clinical results of the treatment of diabetes mellitus with chlorpropamide. Ann NY Acad Sci 1959;74:891-9.

${ }^{5}$ Bloch J, Lenhardt A. Advantages and disadvantages of shifting patients from tolbutamide to chlorpropamide. Ann NY Acad Sci 1959;74: 954-61.

${ }^{6}$ Leslie RDG, Pyke DA. Chlorpropamide alcohol flushing: a dominantly inherited trait associated with diabetes. Br Med f 1978;ii:1519-21.

${ }^{7}$ Wolff PM. Ethnic differences in alcohol sensitivity. Science 1972;175 449-50.

${ }^{8}$ Wolff PM. Vasomotor sensitivity to alcohol in diverse mongoloid populations. Am 7 Hum Genet 1973;25:193-9.

${ }^{9}$ Fitzgerald MG, Gaddie R, Malins JM, O'Sullivan DJ. Alcohol sensitivity in diabetics receiving chlorpropamide. Diabetes 1962;11:40-3.

10 Pyke DA, Leslie RDG. Chlorpropamide alcohol flushing; a definition of its relation to non insulin-dependent diabetes. $\mathrm{Br}$ Med $\mathcal{7} 1978$;ii:1521-2.

${ }^{11} \mathrm{Keen} \mathrm{H}, \mathrm{Ng}$ Tang Fui S. The definition and classification of diabetes mellitus. Clin Endocrinol Metab 1982;11:279-305.

${ }^{12}$ Barnett AH, Spiliopoulous AJ, Pyke DA. Blockade of chlorpropamide alcohol flushing by indomethacin suggests an association between prostaglandins and diabetic vascular complications. Lancet 1980;ii: 164-6.

${ }^{13}$ Strakosch CR, Jefferys DB, Keen $\mathbf{H}$. Blockade of chlorpropamide alcohol flush by aspirin. Lancet 1980;i :394-6. 
14 Pyke DA, Johnston C. Commentary on Wilkin's paper. Metabolism $1982 ; 31$ :955-8.

${ }^{15}$ Kobberling J, Bengsch N, Bruggeboes B, Schwark H, Tillil H, Weber M The chlorpropamide alcohol flush. Lack of specificity for familial non insulin-dependent diabetes. Diabetologia 1980;19:359-63.

${ }^{16}$ De Silva NE, Tunbridge WMG, Alberti KGMM. Low incidence of chlorpropamide alcohol flushing in diet-treated, non insulin-dependent diabetes. Lancet $1981 ; \mathrm{i}: 128-31$.

${ }^{17}$ Carlozzi M, Iezzoni DC, Silver L. Blood levels of chlorpropamide in normal men following chronic administration. Ann NY Acad $\mathrm{Sc}$ $1959 ; 74: 788-93$.

${ }^{18}$ Jerntorp P, Almer LO, Melander A. Is blood chlorpropamide concentration critical in the chlorpropamide alcohol flush ? Lancet $1981 ; \mathrm{i}: 165-6$

${ }^{19} \mathrm{Ng}$ Tang Fui S, Keen H, Jarrett J, Gossain V, Marsden P. Test for chlorpropamide alcohol flush becomes positive after prolonged chlorpropamide treatment in insulin-dependent and non insulin-dependent diabetics. N Engl f Med 1983;309:93-6.
${ }^{20}$ Pontiroli AE, De Pasqua A, Colombo R, Ricordi C, Pozza G. Characterisation of the chlorpropamide alcohol flush in patients with type $I$ and type II diabetes. Acta Diabetol Lat (in press).

${ }^{21}$ Jefferys DB, Keen $\mathrm{H}, \mathrm{Ng}$ Tang Fui S. Chlorpropamide alcohol flush. Lancet $1981 ; \mathrm{i}: 440$.

${ }^{22}$ Radder JK, Box MCJG, Lemkes HMPJ. Facial skin temperature and the chlorpropamide alcohol flush in diabetics. Lancet 1980;ii:1037.

${ }^{23}$ Ohlin H, Jerntorp P, Bergström B, Almer L-O. Chlorpropamide alcohol flushing, aldehyde dehydrogenase activity and diabetic complications. $\mathrm{Br}$ Med f 1982;285:833-40.

${ }^{24}$ Barnett AH, Gonzalez-Auvert C, Pyke DA, et al. Blood concentration of acetaldehyde during chlorpropamide alcohol flush. $\mathrm{Br} \mathrm{Med} \mathcal{F} 1981$ $283: 939-41$

(Accepted 7 September 1983)

\section{SHORT REPORTS}

\section{Heberden's nodes in osteoarthritis and rheumatoid arthritis}

William Heberden was the first to describe the firm swellings of the distal interphalangeal joints that are now regarded as characteristic of generalised osteoarthritis. ${ }^{1}$ Rheumatoid arthritis causes soft swellings around metacarpophalangeal and proximal interphalangeal joints but is usually thought to spare the distal interphalangeal joints. ${ }^{2}$ Clinical abnormalities of the distal interphalangeal joints in patients with rheumatoid arthritis have been noted, however, ${ }^{34}$ and generalised osteoarthritis and rheumatoid arthritis may coexist more often than would be expected by chance, ${ }^{5}$ but no controlled data are available. We made a comparative study of clinical and radiological changes in the distal interphalangeal joints in rheumatoid arthritis and generalised osteoarthritis.

\section{Patients, methods, and results}

One hundred consecutive outpatients attending a rheumatology clinic with classical or definitive rheumatoid arthritis (American Rheumatism Association criteria) were compared with 40 patients with generalised osteoarthritis and 42 controls matched for age and sex admitted to hospital for non-rheumatic disorders. Their hands were examined by the same observer, and individual distal interphalangeal and proximal interphalangeal joints were given scores from 0 to $3(0=$ normal, $1=$ firm swelling, $2=$ sof swelling, $3=$ swollen, hot, and tender). Age, sex, duration of disease, and presence of rheumatoid factor were also noted. Anterior-posterior hand radiographs were examined by a radiologist who was unaware of the clinical findings; seven different features were scored as present or absent (table).

Incidence of seven radiographic abnormalities in distal interphalangeal joints in patients with generalised osteoarthritis or rheumatoid arthritis and in control group (figures are numbers $(\%)$ of patients)

\begin{tabular}{lccc}
\hline \multicolumn{1}{c}{ Abnormality } & $\begin{array}{c}\text { Group with } \\
\text { osteoarthritis } \\
(\mathrm{n}=\mathbf{4 0})\end{array}$ & $\begin{array}{c}\text { Group with } \\
\text { rheumatoid } \\
\text { arthritis } \\
(\mathrm{n}=100)\end{array}$ & $\begin{array}{c}\text { Control } \\
\text { group } \\
(\mathrm{n}=\mathbf{4 2})\end{array}$ \\
\hline Osteophytes & $\mathbf{4 0}(100)$ & 82 & $31(74)$ \\
Subchondral cysts & $34(85)$ & 61 & $8(18)$ \\
Ossicles & $33(83)$ & 38 & $15(36)$ \\
Joint space narrowing & $33(83)$ & 60 & $16(38)$ \\
Soft tissue swelling & $37(93)$ & 76 & $6(15)$ \\
Juxta-articular osteoporosis & $1(2 \cdot 5)$ & 33 & 0 \\
Ill defined erosions & 0 & 12 & 0 \\
\hline
\end{tabular}

The mean age of the group with rheumatoid arthritis was $57 \cdot 7$ (SD 12.3); mean duration of symptoms was 9.7 years. Eighty one patients were positive for rheumatoid factor on latex agglutination testing, and the ratio of men to women was $1: 2 \cdot 5$. The mean age of the group with generalised osteoarthritis was $65.8(10.2)$ and mean duration of symptoms 7.8 years; none was seropositive, and the ratio of men to women was $1: 4 \cdot 7$. The control group was well matched with the group with rheumatoid arthritis (mean age $59 \cdot 1(12 \cdot 9), \mathrm{M}: \mathrm{F}=1: 2 \cdot 5)$

Clinical abnormalities of the distal interphalangeal joints were seen in
$67(67 \%)$ of the patients with rheumatoid arthritis compared with $33(92 \%)$ of the patients with generalised osteoarthritis and $17(41 \%)$ of the controls (group with rheumatoid arthritis versus controls: $\chi^{2}=15 \cdot 2, p<0 \cdot 01$ ) Grade 2 or 3 changes were seen in $12(12 \%)$, nine $(24 \%)$, and two $(5 \%)$ patients respectively. The changes in the group with rheumatoid arthritis were often clinically indistinguishable from those in the group with osteoarthritis. The table summarises the radiological findings.

The soft tissue swelling of the distal interphalangeal joints was common in both osteoarthritis and rheumatoid arthritis, but not in the control group. Juxta-articular osteoporosis and ill defined erosions were present in the distal phalangeal joints in 33 and 12 patients respectively with rheumatoid arthritis but were not seen in patients with osteoarthritis or in controls. Subchondral cysts were also commoner in the groups with osteoarthritis and rheumatoid arthritis than in the control group $(\mathrm{p}<0.01)$. Osteophytes, ossicles, and narrowing of the joint space were common in all three groups of patients.

\section{Comment}

This study confirms previous reports suggesting that the distal interphalangeal joints are often affected in rheumatoid arthritis. ${ }^{3}$ The changes were often clinically indistinguishable from Heberden's nodes and occurred more commonly in these patients than in the control population. Radiological changes included typical features of rheumatoid arthritis such as juxta-articular osteoporosis (33\%) and ill defined erosions $(12 \%)$. Of the 12 patients with rheumatoid erosions of the distal interphalangeal joints, 10 were strongly seropositive and all had typical rheumatoid changes at other joint sites. There was no evidence of psoriatic arthropathy or juvenile chronic arthritis.

This study shows that rheumatoid arthritis does not spare the distal interphalangeal joints. Furthermore, clinical detection of a Heberden's node does not necessarily imply the presence of generalised osteoarthritis.

We are grateful to the Arthritis and Rheumatoid Council for financial support.

${ }^{1}$ Kellgren JH, Moore R. Generalised osteoarthritis and Heberden's nodes. Br Med f 1952;i:181-7.

${ }^{2}$ Resnick D, Niwayama G. Diagnosis of bone and joint disorders. Philadelphia WB Saunders, 1981.

${ }^{3}$ McCarty DJ Jr, Gatter RA. A study of distal interphalangeal join tenderness in rheumatoid arthritis. Arthritis Rheum 1966;9:325-35.

4 Fleming A, Crown JM, Corbett M. Early rheumatoid disease. I. Onset. Ann Rheum Dis 1976;35:357.

${ }^{5}$ Ehrlich GE. Osteoarthritis beginning with inflammation. Definitions and correlations. $\mathcal{F} A M A$ 1975;232:157-9.

(Accepted 1 August 1983)

University Departments of Medicine and Radiodiagnosis, Bristol Royal Infirmary, Bristol BS2 8HW

GILES CAMPION, $\mathrm{MB}, \mathrm{CHB}$, house physician

PAUL DIEPPE, MB, MRCP, senior lecturer in rheumatology

IAIN WATT, MRCP, FRCR, consultant radiologist

Correspondence to: Dr P Dieppe. 